\title{
Copper toxicity on the marine microalga Phaeodactylum tricornutum: effects on photosynthesis and related parameters
}

\author{
Ángeles Cid, Concepción Herrero, Enrique Torres, Julio Abalde ${ }^{1}$
}

Aquatic Toxicology, Volume 31, Issue 2, February 1995, Pages 165-174

Received 2 March 1994, Revised 1 August 1994, Accepted 3 August 1994, Available online 28

April 2000

DOI: 10.1016/0166-445X(94)00071-W

\begin{abstract}
Essential heavy metals, as copper, can be toxic for microalgae at high concentrations. Copper affected growth and other parameters closely related to photosynthesis of the marine diatom Phaeodactylum tricornutum. A copper concentration of $0.10 \mathrm{mg} \mathrm{I}^{-1}$ provoked about $50 \%$ growth reduction and $1 \mathrm{mg} \mathrm{I}^{-1}$ inhibited the growth. Copper also interfered with photosynthesis and ATP production. A copper concentration of $0.5 \mathrm{mg} \mathrm{l}^{-1}$ reduced in a $50 \%$ the photosynthetic rate. Therefore, growth is more affected by copper than photosynthesis. Results of chlorophyll a fluorescence obtained by flow cytometry showed that copper's inhibitory effect on PS II activity is located on its oxidizing side. The lower copper concentration assayed provoked a significant decrease in the cellular pool of ATP. Pigment analysis by HPLC showed that copper affected the pigment pattern of $P$. tricornutum. Important changes were observed for chlorophyll $a$ and its allomer: chlorophyll a proportion decreased while its allomer increased with the copper concentration, being maximum at $1 \mathrm{mg} \mathrm{Cu} \mathrm{I}^{-1}$. The study of the intracellular $\mathrm{pH}$ by flow cytometry revealed that $P$. tricornutumcells exposed to 0.5 and $1 \mathrm{mg} \mathrm{Cu} \mathrm{I}^{-1}$ showed an intracellular $\mathrm{pH}$ higher than control cultures cells, explaining the high proportion of the chlorophyll a allomer in these cells.
\end{abstract}

\section{Keywords}

Copper toxicity; Phaeodactylum tricornutum; Photosynthesis; Flow cytometry

\footnotetext{
${ }^{1}$ Laboratorio de Microbiología, Departamento de Biología Celular y Molecular, Facultad de Ciencias, Universidad de La Coruña, Campus da Zapateira s/n, 15071 La Coruña, Spain
} 


\section{Introduction}

Heavy metals are among the most frequently identified pollutants in aquatic environments. From a biological point of view, heavy metals can be divided in two categories: essential and nonessential. However, essential heavy metals have been also reported to be toxic at high concentrations. Many of these metals have a direct influence on various physiological and biochemical processes. Heavy metals are known to interfere with a variety of photosynthetic functions (Clijsters and Van Assche, 1985; Mohanty and Mohanty, 1988; Murthy et al., 1989).

Copper is an essential micronutrient for growth, metabolism and enzyme activities of various algae, cyanobacteria and other organisms; however, it is also a proven inhibitor of algal growth at high concentrations (Erickson, 1972).

Different aspects of copper toxicity on micro algae were evaluated in the marine diatom Phaeodactylum tricornutum. Parameters closely associated with photosynthesis, such as radioactive carbon assimilation, ATP concentration and photosynthetic pigment pattern, were evaluated, besides growth rate, the classical parameter utilized in toxicity assays.

\section{Materials and methods}

Algae cultures. Phaeodactylum tricornutum Bohlin (Bacillariophyceae) (isolated from Ria de Arousa waters by Dr. J. Fabregas, University of Santiago, Spain) was cultured in batch conditions in natural seawater filtered through a $0.45 \mu \mathrm{m}$ Millipore filter; after that, this filtered seawater was newly filtered through an active carbon filter to eliminate organic chelating substances, and autoclaved at $120^{\circ} \mathrm{C}$ for $60 \mathrm{~min}$. The assays were carried out in this raw, unenriched, sea water, with no inorganic nutrients added. Copper concentrations assayed were $0.05,0.10,0.50$ and $1 \mathrm{mg} \mathrm{Cu} \mathrm{I}^{-1}$, added as copper chloride; control cultures without copper were also included. The free copper ion concentration in each culture was quantified (Abalde et al., 1994), showing that in this range of concentrations, all copper added to the cultures appeared as free copper ion. Salinity of seawater was $35 \%_{0}$ and the initial $\mathrm{pH}$ of the cultures was 7.6. Cultures were grown in KIMAX test tubes, containing $40 \mathrm{ml}$ of medium. The tubes were previously rinsed with nitric acid and washed several times with redistilled water. Cultures were maintained at $18 \pm 1^{\circ} \mathrm{C}$ and $140 \mu \mathrm{mol}$ photon $\mathrm{m}^{-2} \mathrm{~s}^{-1}$, with a dark: light cycle of $12: 12 \mathrm{~h}$. Initial cell density was $24 \times 10^{4}$ cells $\mathrm{m} \mathrm{I}^{-1}$. All experiments were carried out in triplicate.

Measurement of growth. Growth of the microalgal cultures was measured by counting culture aliquots in a Neubauer hemocytometer. Microalgal growth is characterized by a sigmoid or logistic function. The form of the logistic growth function used at the present work was (Schanz and Zahler, 1981):

$$
y(t)=K \llbracket[1+B \exp (-z t)]
$$


where $y(t)$ represents the cell density at time $t$ and $K$ its ultimate limiting value ('carrying capacity'). $B$ is a biologically unimportant constant, and its value was calculated by the following equation: $B=\left(K-y_{0}\right) / K-y_{0}$. The parameter $z$ is related with growth rate. All the parameters of the equation were fitted by non-linear regression using Marquadt's algorithm.

Measurement of photosynthesis. The effect of copper on photosynthesis was determined by estimation of carbon fixation, recording the uptake of ${ }^{14} \mathrm{C}$ from $\mathrm{NaH}^{14} \mathrm{CO}_{3}{ }^{14} \mathrm{C}$-bicarbonate (Amersham, $674 \mu \mathrm{Ci} \mathrm{mg}{ }^{-1}$ ) was added to the micro algal suspensions in culture tubes to give an activity of $0.01 \mu \mathrm{Ci} \mathrm{mg}{ }^{-1}$. Incubation periods tested were $0.5,1,2$ and $4 \mathrm{~h}$, and the photosynthetically fixed radioactivity in microalgal cells was counted in a LKB scintillation counter with Readysafe (Beckman) as scintillator.

Determination of ATP. ATP extraction was carried out using the method of Holm-Hansen (1970), as described by Larsson and Olsson (1979), after $8 \mathrm{~h}$ of copper exposure. ATP concentration was determined using a commercial bioluminescence assay CATP bioluminescence CLS', Boehringer-Mannheim) based in the luciferin-luciferase reaction. The constant light signal produced in this reaction was measured in a LKB scintillation counter.

Chlorophyll a. The analysis of chlorophyll a was carried out after $24 \mathrm{~h}$ of copper exposure. Pigments were extracted in acetone $90 \%$ at $4{ }^{\circ} \mathrm{C}$, in dark conditions, and concentrated by evaporation of the solvent. Dry extracts of pigments were resuspended in $100 \mu \mathrm{l}$ of methanol (HPLC grade). The HPLC analysis of photosynthetic pigments was carried out as Wright et al. (1991).

Chlorophyll a was also determined spectrophotometrically; the concentration was calculated using the formula of Jeffrey and Humphrey (1975).

Flow cytometry determinations. Chlorophyll a fluorescence and intracellular $\mathrm{pH}$ were determined after 8 and 24 of copper exposure by flow cytometry (FCM), using a FACScan flow cytometer (Becton Dickinson Instruments), equipped with an argonion excitation laser (488 nm). Propidium iodide (final concentration: $60 \mu \mathrm{M}$ ) was used to counterstain the DNA of dead cells. Forward light scatter (FSC), which can be correlated with the size of the cell, and the fluorescence of the propidium iodide $(\mathrm{PI})$, which can be correlated with the viability of the cells, were used to set gating levels. In the study of chlorophyll a fluorescence, aliquots of micro algal cultures were directly analyzed in the flow cytometer. The chlorophyll a fluorescent emission was collected in the FL3 $(660 \mathrm{~nm})$ channel.

The FCM technique used for the determination of variations in the intracellular $\mathrm{pH}$ is based on the $\mathrm{pH}$-dependent emission intensity of a fluorescein derivate, 2'-7'-dichlorofluorescein (DC F)

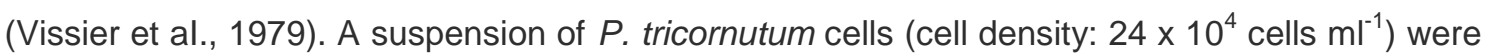
stained with this fluorescent compound and analyzed in the flow cytometer. Final DCF concentration achieved was $20 \mu \mathrm{M}$; the green fluorescent emission of this compound was collected in the FLI $(530 \mathrm{~nm})$ channel. 
Data analysis. Data were statistically analyzed by an one-way analysis of variance (ANOVA) and, when differences observed were significatives, means were compared by the multiple range Duncan test, at a level of significance of 0.05 .

For each cytometric parameter investigated, 104 events (cells) were analyzed per condition and fluorescence measurements were in the logarithmic scale. Data collection was performed using the list mode. The mean of fluorescence for any given population was provided by the instrument software (LYSIS II program; Becton Dickinson Instruments).

Data on chlorophyll a fluorescence and intracellular $\mathrm{pH}$ of $\mathrm{P}$ tricornutum cells were expressed as a percentage (\%) of the fluorescence of the control cells according to the equation of Reader et al. (1993):

$\% F=100-\left[100\left(F_{\mathrm{c}}-F_{\mathrm{t}}\right) / F_{\mathrm{c}}\right]$

where $\% F$ is the percentage of fluorescence of the $P$ tricornutum cells; $F_{\mathrm{c}}$ the mean fluorescence of control cells; and $F_{\mathrm{t}}$ mean fluorescence of copper-treated cells.

\section{Results}

\subsection{Growth}

Phaeodactylum tricornutum grew in all copper concentrations assayed except in cultures with 1 $\mathrm{mg} \mathrm{Cu}^{-1}$ (Table I). Maximum cell density was reached in control cultures, with $149.25 \times 10^{4}$ cells $\mathrm{ml}^{-1}$; maximum cell density achieved in cultures with $0.05 \mathrm{mg} \mathrm{Cu} \mathrm{l}^{-1}\left(135.00 \times 10^{4}\right.$ cells ml$\left.^{-1}\right)$ was not significantly different than that obtained in control cultures $(P<0.05)$. A copper concentration of $0.10 \mathrm{mg} \mathrm{Cu} \mathrm{r}^{-1}$ provoked an strong decrease in growth, and maximum cell density obtained in these cultures was about a $50 \%$ lower than those reached in control cultures (Table 1).

Microalgal growth is characterized by a sigmoid or logistic function and the parameters of their mathematical functions are also shown in Table 1. The growth of the cultures with I mg Cu l-1 did not fit to the logistic function. The carrying capacity calculated with this function correlated well with the maximum cell density observed experimentally (Table 1).

Table 1: Maximum cellular densities (expressed in cells $\times 10^{4} \mathrm{ml}^{-1}$ ), logistic growth function parameters and cellular content in chlorophyll a $\left(\mathrm{pg} \mathrm{cell}{ }^{-1}\right)$ obtained in cultures of Phaeodactylum tricornutum exposed to different copper concentrations, expressed as $\mathrm{mg} \mathrm{I}^{-1}$ 
Logistic function parameters

\begin{tabular}{lllllll}
\cline { 3 - 6 } Cu & Maximum density & $K$ & $B$ & $z$ & $r$ & Chlorophyll $a$ \\
\hline Control & $149.25 \pm 11.93$ & 157.40 & 7.67 & 1.59 & 0.99 & $0.06 \pm 0.003$ \\
0.05 & $135.00 \pm 14.25$ & 147.00 & 6.85 & 1.29 & 0.99 & $0.08 \pm 0.004$ \\
0.10 & $71.62 \pm 9.87$ & 76.62 & 2.41 & 1.03 & 0.99 & $0.11 \pm 0.009$ \\
0.50 & $37.50 \pm 1.80$ & 36.50 & 0.53 & 0.75 & 0.85 & $0.08 \pm 0.003$ \\
1.0 & $24.00 \pm 3.00$ & - & - & - & - & $0.09 \pm 0.006$
\end{tabular}

Fig, I. Photosynthetic rate as assimilated carbon ( $\mu \mathrm{g} \mathrm{I}^{-1} \mathrm{~h}^{\mathrm{h}-1}$ ) and intracellular ATP content $\left(\mathrm{nmol} \times 10^{-6}\right.$ cell $^{-1}$ ) of Phaeodactylum tricornutum cells exposed to different copper concentrations $\left(\mathrm{mg} \mathrm{I}^{-1}\right)$,

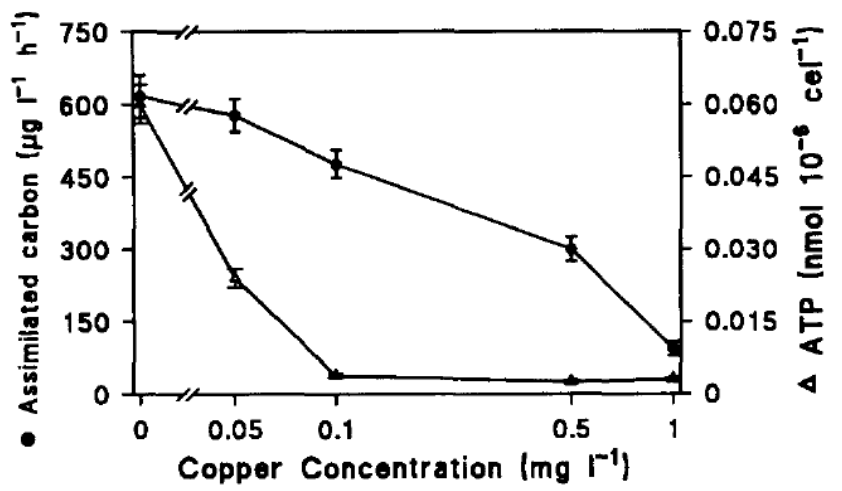

\subsection{Photosynthesis}

Photosynthesis, expressed as ${ }^{14} \mathrm{C}$-bicarbonate assimilated $\left(\mu \mathrm{g} \mathrm{C} 1^{-1} \mathrm{~h}^{-1}\right)$, decreased when copper concentration increased (Fig. 1). After $4 \mathrm{~h}$ of metal exposure, copper concentrations of $0.05 \mathrm{mg} \mathrm{I}^{-1}$ and higher provoked a strong decrease in the photosynthetic rate. In control cultures the photosynthetic rate was $617.81 \mathrm{~g} \mathrm{C} \mathrm{I}^{-1} \mathrm{~h}^{-1}$, whereas in cultures with I $\mathrm{mg} \mathrm{Cu} \mathrm{I}^{-1}$ this rate was $94.28 \mathrm{\mu g} \mathrm{C} \mathrm{I}^{-1} \mathrm{~h}^{-1}$, significantly lower than that obtained in control cultures.

\subsection{ATP}

Results obtained showed that the ATP content of Phaeodactylum tricornutum cells was drastically affected by copper (Fig. I). Intracellular ATP concentration in control cultures was $0.060 \mathrm{nmol}$ ATP $\times 10^{-6}$ cells; this value decreased when copper concentration increased, being $0.004 \mathrm{nmol} \times 10^{-6}$ cells in cultures with $0.1 \mathrm{mg} \mathrm{Cu} \mathrm{l}^{-1}$. There were no significant differences between these cultures $\left(0.1 \mathrm{mg} \mathrm{Cu} 1 \mathrm{I}^{-1}\right)$ and cultures with higher copper concentrations.

\subsection{Chlorophylls}

Cell contents of chlorophyll a of Phaeodactylum tricornutum, calculated from spectrophotometric data, are shown in Table 1. Chlorophyll a content increased when copper concentration increased to $0.1 \mathrm{mg} \mathrm{Cu} \mathrm{l}^{-1}\left(0.11 \mathrm{pg} \mathrm{cell}^{-1}\right)$. Copper concentrations higher than $0.1 \mathrm{mg} \mathrm{l}^{-1}$, provoked a decrease in chlorophyll a content (Table 1). 
The analysis of pigments by HPLC showed that copper affected the pigment pattern of $P$ tricornutum after $24 \mathrm{~h}$ of copper exposure. In the figure 2 are represented the chlorophylls expressed as percentage of the total pigments resolved by HPLC (chlorophylls, xanthophylls and carotenoids). Important changes were observed for chlorophyll $a$ and its allomer. The proportion of the chlorophyll a allorner increased when copper concentration increased in the medium, while the proportion of chlorophyll a decreased (Fig. 2). The maximum proportion of chlorophyll a was observed in cultures with $0.1 \mathrm{mg} \mathrm{Cu} \mathrm{II}^{-1}$ (70.54\%), whereas the proportion of the chlorophyll a allomer in these cultures was $6.97 \%$. Higher concentrations of copper provoked an inversion in the proportions of both pigments: chlorophyll a decreased while its allomer increased, being maximum at $1 \mathrm{mg} \mathrm{Cu}^{-1}(39.31 \%)$.

Fig. 2. Relationship between chlorophyll $a$ and its allomer (expressed as percentage of total pigments) in Phaeodactylum tricornutum cells exposed to different copper concentrations $\left(\mathrm{mg}^{-1}\right) \quad(r=$ 0.99).

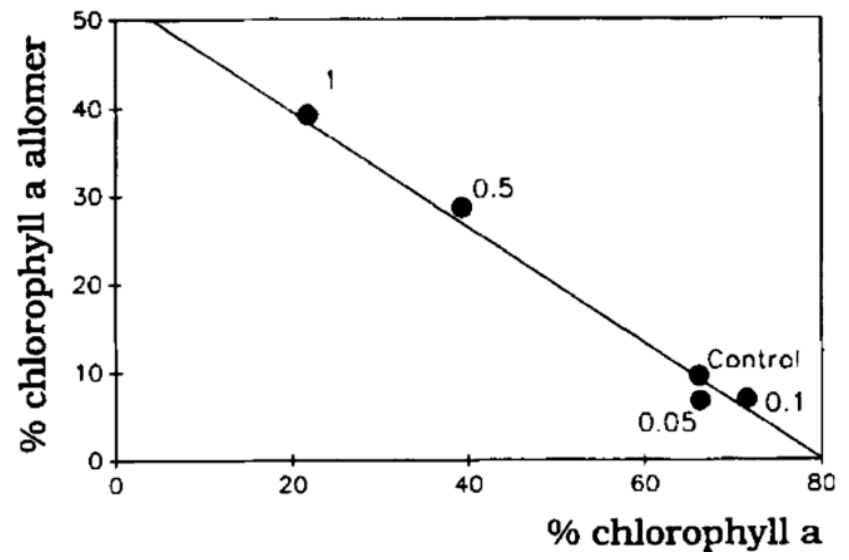

The proportions of chlorophyll a and its allomer showed a negative correlation (Fig. 2). There were not significant differences in this ratio among control cultures and cultures with 0.05 and $0.10 \mathrm{mg} \mathrm{Cu} \mathrm{I}^{-1}$, but higher concentrations of copper provoked an inversion of this ratio.

Fig. 3. Chlorophyll a fluorescence after copper exposure in Phaeodactylum tricornutum cells. Data on chlorophyll a fluorescence are expressed as the percentage of the fluorescence of control cells, according to the equation of Reader et al. (1993). Results are the means of three replicates.

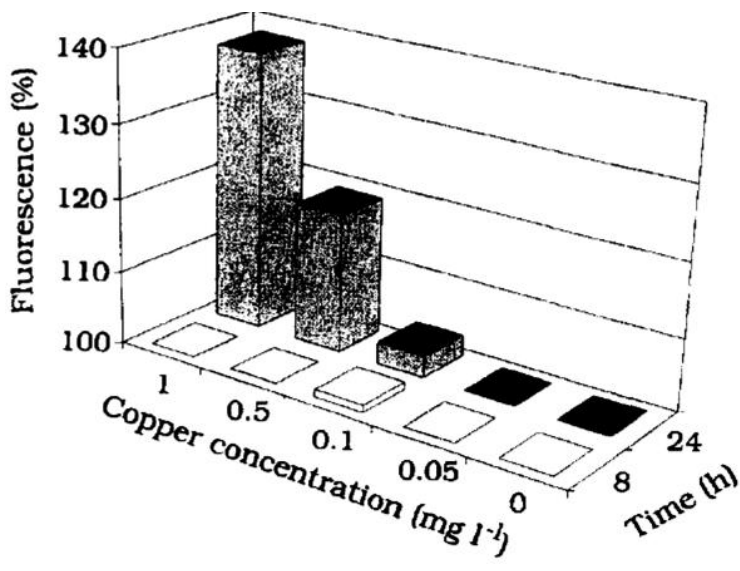


Fig. 4. Intracellular $\mathrm{pH}$ after copper exposure in Phaeodactylum tricornutum cells. 2'.7'-dichlorofluorescein was used as the fluorescent probe to evaluate intracellular $\mathrm{pH}$. Data on intracellular $\mathrm{pH}$ are expressed as the percentage of the fluorescence of control cells, according to the equation of Reader et al. (1993). Results are the means of three replicates.

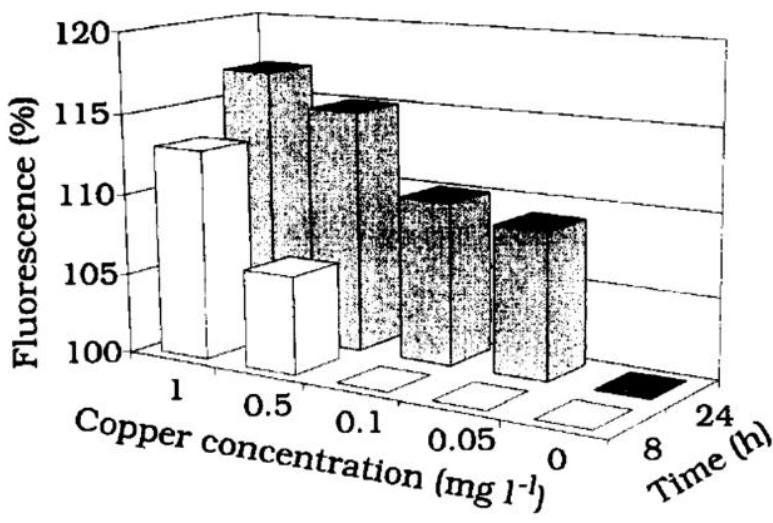

\subsection{Chlorophyll a fluorescence}

The study of chlorophyll a fluorescence by flow cytometry showed a significant increase in this fluorescence in Phaeodactylum tricornutum cells exposed to 0.5 and I mg Cu l-1, after $24 \mathrm{~h}$ of metal exposure (Fig. 3). If the percentage of chlorophyll a fluorescence in control cultures is $100 \%$, the fluorescence increase in affected cells was $19 \%$ and $38 \%$, in cultures with 0.5 and 1 $\mathrm{mg} \mathrm{Cu} 1^{-1}$. respectively. After $8 \mathrm{~h}$ of copper exposure the differences were not significant.

\subsection{Intracellular pH}

As copper concentration increased in the medium, an increase of the intracellular $\mathrm{pH}$ was observed in cells of Phaeodactylum tricornutum analyzed for this purpose by flow cytometry (Fig. 4). Cells exposed to 0.5 and $\mathrm{I} \mathrm{mg} \mathrm{Cu} \mathrm{I}^{-1}$ were the most affected after $24 \mathrm{~h}$ of metal exposure; in these cultures, the fluorescence emitted by the cells, stained with the fluorescein derivate used, accounted for 115 and $117 \%$ than the fluorescence observed in the stained control cultures cells (Fig. 4).

\section{Discussion}

One of the most studied toxic effect of copper on microorganisms is the effect on growth. Copper concentration that affects growth in micro algae is largely variable and depends on the species assayed, cell density, composition of the medium, physical culture conditions, etc. (Whitton, 1968; Stauber and Florence, 1985a). At the present work, a copper concentration of $0.10 \mathrm{mg}^{-1}$ provoked about 50\% growth reduction of Phaeodactylum tricornutum, and $1 \mathrm{mg} \mathrm{I}^{-1}$ inhibited the growth (Table I). At the cell membrane, copper may interfere with cell permeability or the binding of essential metals (Sunda and Huntsman, 1983). Following copper transport into the cytosol, copper may react with -SH enzyme groups and free thiols (e.g. glutathione), disrupting enzyme-active sites and cell division (Stauber and Florence, 1985b; Florence and Stauber, 1986). 
Copper may also exert its toxicity in subcellular organelles, interfering with photosynthesis in the chloroplasts (Overnell, 1975) and ATP production (Viarengo et al., 1981). Photosynthesis inhibition by copper has been observed previously in other diatoms (Erickson, 1972; Overnell, 1975; Stauber and Florence, 1987). As growth, copper concentration that affects photosynthesis depends on the species assayed. Wong and Chang (1991) have observed that $0.1 \mathrm{mg} \mathrm{Cu} 1^{-1}$ produced a slight inhibition of photosynthesis in Chlorella pyrenoidosa, while 0.25 $\mathrm{mg} 1^{-1}$ produced total inhibition.

Results obtained in the present work showed that the photosynthesis rate of $P$. tricornutum cultures decreased when copper concentration increased; $0.5 \mathrm{mg} \mathrm{Cu} 1^{-1}$ reduced in a $50 \%$ the photosynthetic rate (Fig. 1). Therefore, growth is more affected by copper than photosynthesis. This uncoupling between division rate and photosynthesis can be due to copper inhibits the process of cell division indepedently of any effect on the production of new cell material (Stauber and Florence, 1987).

Chlorophyll a fluorescence is particularly sensitive to the functioning of photosystem II (PS II). Measurement of the fluorescence of chlorophyll a in intact algal cells provides information on the absorption, distribution and utilization of energy in photosynthesis (Papageorgiou, 1975; Fork and Mohanty, 1986). Algal fluorescence induction phenomena were used to study phytotoxicity (Moody et al., 1983; Samson and Popovic, 1988). Chlorophyll a fluorescence monitored by the single-laser-based flow cytometer is the maximum fluorescence when the PS II reaction centers are locked in the $Q_{A}$ - state (Xu et al., 1990). It is known that the inhibition of the electron flow in the PS II reaction center at the donor side provokes a decrease in the chlorophyll a fluorescence, while if the inhibition is produced in the acceptor side of the PS II, an increase in the chlorophyll a fluorescence is observed (Butler, 1977; Samson et al., 1988; Murthy et al., 1990). In accordance with Samson et al. (1988), chlorophyll a fluorescence results obtained by flow cytometry (Fig. 3) show that copper's inhibitory effect on PS II activity is located on its oxidizing side, probably because copper inactivates some PS II reactions centers.

Photosynthesis is driven by two photosystems, I and II, leading to the oxidation of $\mathrm{H}_{2} \mathrm{O}$ to molecular $\mathrm{O}_{2}$, to the reduction of a pyridine nucleotide, and to the production of ATP. So any compound which affects photosynthesis, would also be expected to alter the ATP intracellular content. Results obtained showed that minimum copper concentrations assayed $\left(0.05 \mathrm{mg} \mathrm{I}^{-1}\right)$ provoked a significant decrease in the cellular pool of ATP in P tricornutum cells (Fig. 1). This copper concentration had no effect on photosynthesis; this fact can be explained by a higher consumption of ATP in the cell to avoid the toxic effects of copper, maintaining cellular integrity and activating metabolic processes related with cell growth; results obtained showed that growth was not affected by $0.05 \mathrm{mg} \mathrm{Cu} 1^{-1}$, which reduced the ATP content.

The pigment composition of diatoms is a consequence of environmental factors (Klein, 1988). Klein (1988) has suggested that chlorophyll a allomer is related to active growth in no stress conditions; the chlorophyll a: chlorophyll a allomer ratio is lowest during the period of active 
growth and increases when growth declines. However, in Phaeodactylum tricornutum cultures with 0.5 and $1 \mathrm{mg} \mathrm{Cu} 1^{-1}$ the growth was inhibited and cells presented a higher proportion of chlorophyll a allomer than chlorophyll a (Fig. 2). Chlorophyll a allorner is produced by the oxidation of chlorophyll $a$ at alkaline $\mathrm{pH}$. The study of the intracellular $\mathrm{pH}$ by flow cytometry revealed that $P$ tricornutum cells exposed to 0.5 and $1 \mathrm{mg} \mathrm{Cu}^{-1}$ showed an intracellular $\mathrm{pH}$ higher than control cultures cells (Fig. 4), explaining the high proportion of the chlorophyll a allomer in these cells.

\section{Acknowledgements}

This work was supported in part by a grant from Dirección General de Investigación Científica y Técnica (DGICYT), Madrid, Spain (No. PB89-0546).

\section{References}

\section{J. Abalde, A. Cid, S. Reiriz, E. Torres, C. Herrero}

Response of the marine microalga Dunaliella tertiolecta (Chlorophyceae) to copper toxicity in short time experiences

Bull. Environ. Contam. Toxicol. (1994) (in press)

W.L. Butler

Chlorophyll fluorescence as a probe for electron transfer and energy transfer

A. Trebst, M. Avron (Eds.), Encyclopedia of Plant Physiology, New Series, Vol. 5Springer, Berlin (1977), pp. 149-167

H. Clijsters, F. Van Assche

Inhibition of photosynthesis by heavy metals

Photosynth. Res., 7 (1985), pp. 31-40

\section{S.J. Erickson}

Toxicity of copper to Thalassiosira pseudonana in unenriched inshore seawater

J. Phycol., 8 (1972), pp. 318-323

\section{T.M. Florence, J.L. Stauber}

Toxicity of copper complexes to the marine diatom Nitzschia closterium

Aquat. Toxicol., 8 (1986), pp. 11-26

D.C. Fork, P. Mohanty

Fluorescence and other characteristics of blue-green algae (Cyanobacteria), red algae and cryptomonads 
J.A. Godvindjee, D.C. Fork (Eds.), Light Emission by Plants and Bacteria, Academic Press, London (1986), pp. 451-496

O. Holm-Hansen

ATP levels in algal cells as influenced by environmental conditions

Plant Cell Physiol., 11 (1970), pp. 689-700

S.W. Jeffrey, G.F. Humphrey

New spectrophotometric equations for determining chlorophylls a, b, c1and c2 in higher plants, algae and natural phytoplankton

Biochem. Physiol. Pflanz., 167 (1975), pp. 191-194

B. Klein

Variations of pigment content in two benthic diatoms during growth in batch cultures

J. Exp. Mar. Biol. Ecol., 115 (1988), pp. 237-248

\section{C.-M. Larsson, T. Olsson}

Firefly assay of adenine nucleotides from algae: comparison of extraction methods

Plant Cell Physiol., 20 (1979), pp. 145-155

N. Mohanty, P. Mohanty

Cation effects on primary processes of photosynthesis

R. Singh, S.K. Sawhney (Eds.), Advances in Frontier Areas of Plant Biochemistry, Prentice-Hall, New Delhi (1988), pp. 1-18

R.P. Moody, P. Weinberger, R. Greenhalgh

Algal fluorometric determination of the potential phytotoxicity of environmental pollutants

O. Nriagu (Ed.), Aquatic Toxicology, 13Wiley Interscience, New York (1983), pp. 504-512

S.D.S. Murthy, S.C. Sabat, P. Mohanty

Mercury-induced inhibition of photosystem II activity and changes in the emission of fluorescence from phycobilisomes in intact cells of the cyanobacterium, Spirulina platensis

Plant Cell Physiol., 30 (1989), pp. 1153-1157

S.D.S. Murthy, N.G. Bukhov, P. Mohanty

Mercury-induced alterations of chlorophyll a fluorescence kinetics in cyanobacteria: multiple effects of mercury on electron transport

J. Photochem. Photobiol. B, Biol., 6 (1990), pp. 373-380

J. Overnell 
The effect of heavy metals on photosynthesis and loss of cell potassium in two species of marine alga Dunaliella tertiolecta and Phaeodactylum tricornutum

Mar. Biol., 29 (1975), pp. 99-103

\section{G. Papageorgiou}

Chlorophyll fluorescence: an intrinsic probe of photosynthesis

A. Govindjee (Ed.), Bioenergetics of Photosynthesis, Academic Press, New York (1975), pp. 319-371

S. Reader, M. Marion, F. Denizeau

Flow cytometric analysis of the effects of tri-n-butylin chloride on cytosolic free calcium and thiol levels in isolated rainbow trout hepatocytes

Toxicology, 80 (1993), pp. 117-129

G. Samson, R. Popovic

Use of algal fluorescence for determination of phytotoxicity of heavy metals and pesticides as environmental pollutants

Ecotoxicol. Environ. Saf., 16 (1988), pp. 272-278

G. Samson, J.C. Morissette, R. Popovic

Copper quenching of the variable fluorescence in Dunaliella tertiolecta. New evidence for a copper inhibition effect on PSII photochemistry

Photochem. Photobiol., 48 (1988), pp. 329-332

F. Schanz, U. Zahler

Prediction of algal growth in batch cultures

Schweiz. Z. Hydrobiol., 43 (1981), pp. 103-113

J.L. Stauber, T.M. Florence

Interactions of copper and manganese: a mechanism by which manganese alleviates copper toxicity to the marine diatom Nitzschia closterium (Ehrenberg) W Smith

Aquat. Toxicol., 7 (1985), pp. 241-254

J.L. Stauber, T.M. Florence

The influence of iron on copper toxicity to the marine diatom Nitzschia closterium (Ehrenberg) W Smith

Aquat. Toxicol., 6 (1985), pp. 297-305

J.L. Stauber, T.M. Florence

Mechanism of toxicity of ionic copper and copper complexes to algae 
Mar. Biol., 94 (1987), pp. 511-519

W.G. Sunda, S.A. Huntsman

The effect of competitive interactions between manganese and copper on cellular manganese and growth in estuarine and oceanic species of the diatom Thalassiosira

Limnol. Oceanogr., 28 (1983), pp. 924-934

A. Viarengo, M. Pertica, G. Mancinelli, R. Capell, M. Orunesu

Effects of copper on the uptake of amino acids, on protein synthesis and on ATP content in different tissues of Mytilus galloprovincialis

Mar. Environ. Res., 4 (1981), pp. 145-152

J.W.M. Vissier, A.A.M. Jongeling, H.J. Tanke

Intracellular $\mathrm{pH}$ determination by fluorescence measurements

J. Histochem. Cytochem., 27 (1979), pp. 32-35

B.A. Whitton

Effect of light on toxicity of various substances to Anacystis nidulans

Plant Cell Physiol., 9 (1968), pp. 23-26

P.K. Wong, L. Chang

Effects of copper, chromium and nickel on growth, photosynthesis and chlorophyll a synthesis of Chlorella pyrenoidosa 251

Environ. Pollut., 72 (1991), pp. 127-139

S.W. Wright, S.W. Jeffrey, R.F.C. Mantoura, C.A. Llewellyn, T. Bjornland, D. Repeta, N. Welschmeyer

Improved HPLC method for the analysis of chlorophylls and carotenoids from marine phytoplankton

Mar. Ecol. Prog. Ser., 77 (1991), pp. 183-196

C. Xu, J. Auger, A. Godvindjee

Chlorophyll a fluorescence measurements of isolated spinach thylakoids obtained by using single-laser-based flow cytometry

Cytometry, 11 (1990), pp. 349-358 